\title{
PARAMETRIC ANALYSES OF DYNAMIC CHARACTERISTIC OF THE CABLE-STAYED PEDESTRIAN BRIDGE
}

\author{
Marek PAŃTAK ${ }^{1}$, Bogusław JAREK \\ Cracow University of Technology, Kraków, Poland
}

\begin{abstract}
The paper presents characteristics of the structural system and results of dynamic field tests and numerical parametric analyses of three-span, two-pylon, cable-stayed pedestrian bridge with steel-concrete composite deck and spans of $25.5+60.0+25.5 \mathrm{~m}$. The footbridge is characterized by increased dynamic susceptibility of the elements of the suspension system observed during the everyday operation of the structure. The analyses have shown that the high amplitude vibrations of the pylon back-stay cables change the parameters of the structural system and consequently change the value of the natural vibration frequencies of the structure. In the paper, the selection methodology of parameters of the computational model which allows to correctly determine the natural vibration frequencies of the footbridge has been presented.
\end{abstract}

Keywords: vibration, footbridges, parametric analysis, cable-stayed bridges, dynamic characteristics

\section{STRUCTURAL CHARACTERISTIC OF THE FOOTBRIDGE}

The footbridge is located in Pcim over the RabaRiver in the immediate vicinity of the S7 expressway known as "Zakopianka". The structure was designed as a three span cable-stayed, composite deck structure with spans of $25.5+60.0+$ 25.5 m (Fig. 1).

\footnotetext{
${ }^{1}$ Corresponding author: D.Eng., Cracow University of Technology, Faculty of Civil Engineering, Department of Bridges and Tunnels Construction, Warszawska st 24, 31-155 Kraków, e-mail: mpantak@pk.edu.pl, tel.: +48126282913
} 


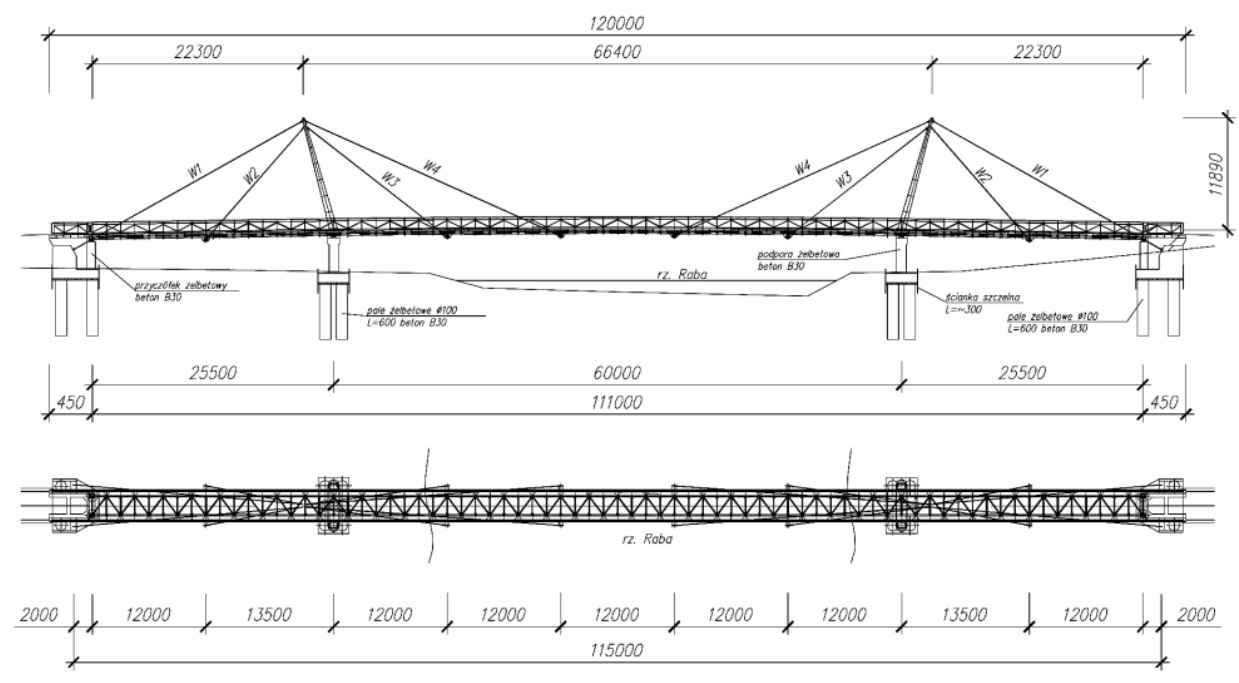

Fig. 1. The structural system of the footbridge [1]

The footbridge deck was designed as a steel-concrete composite deck created with reinforced concrete slab with a thickness of $16-20 \mathrm{~cm}$ made of C30/37 concrete and steel girders of rolled IPE360 beams connected by means of IPE220 crossbeams made of 18G2 steel (Fig. 2 and 5). On the edges of the deck polymer concrete parapet panels $(29 \times 75 \times 4 \mathrm{~cm})$ were used on the edges of the deck.
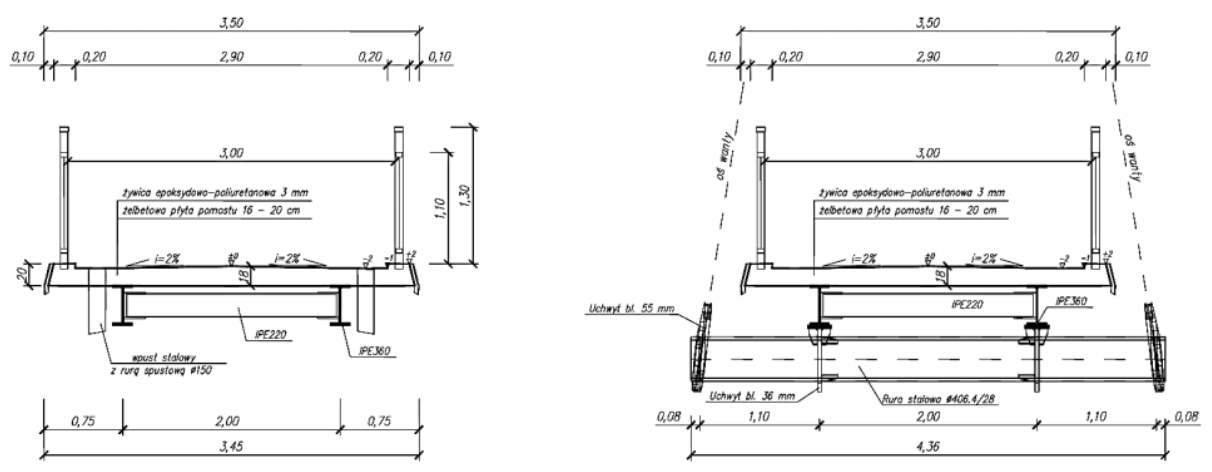

Fig. 2. The cross sections of the footbridge in the middle of the span and at the point of connection of stay rods [1]

The footbridge deck was suspended to two $11.89 \mathrm{~m}$ height steel pylons using Macalloy $460 \mathrm{M} 64$ rods $\varnothing 60 \mathrm{~mm}$. The pylons are made out of plumb at an angle of $15.20^{\circ}$. In the main span four anchor points spaced at $12.0 \mathrm{~m}$ were designed. Side spans were suspended to pylons in one point at a distance of $13.50 \mathrm{~m}$ from the axis of the piers (12.0 $\mathrm{m}$ from the axis of the bridge bearings). The pylons were stabilized by back-stay cables anchored in massive reinforced concrete 
abutments. The piers and abutments were designed of C30/37 concrete and were built on deep pile foundation made of reinforced concrete piles $\varnothing 100 \mathrm{~cm}$

The footbridge pylons (Fig. 3) were designed as steel rectangular box sections of variable geometry made of $12 \mathrm{~mm}$ thick steel plates (18G2 steel). The height of the $30.0 \mathrm{~cm}$ box section is constant over the entire length of the pylon. The section width varies linearly from $80.0 \mathrm{~cm}$ in the bottom of the pylon to $30.0 \mathrm{~cm}$ in the pylon head. The rectangular box sections were stiffened with internal diaphragms spaced at $1512 \mathrm{~mm}$.
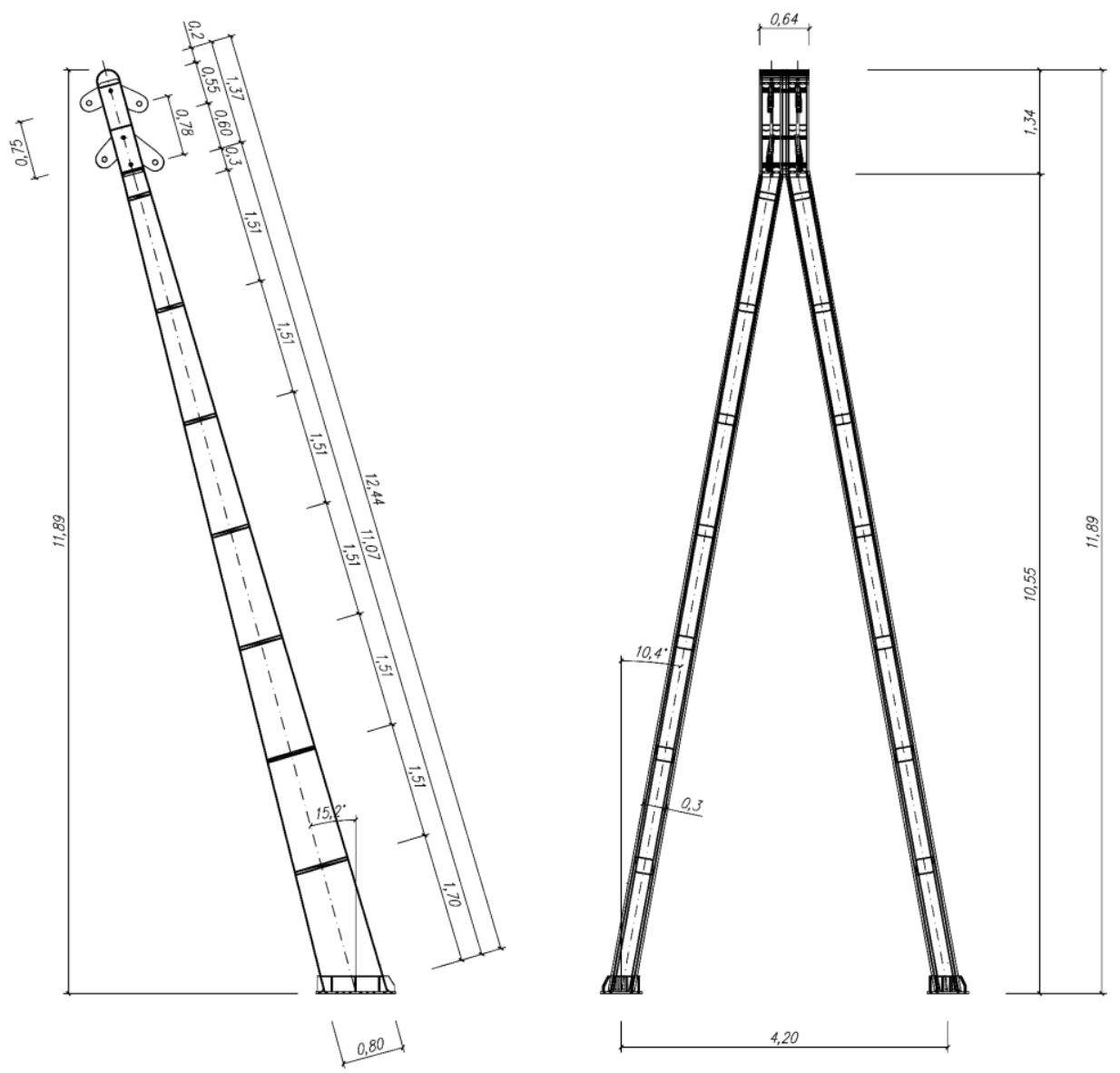

Fig. 3. The pylon structural diagram

The footbridge deck was suspended to the pylons by means of transverse beams of steel pipes $\varnothing 406,4 / 2$, placed under the main girders (Fig. 2 and 4) and highstrength rods with tensioning fittings (Macalloy 460) pivotally connected to the pylons and transverse suspension beams. The length of stay-cables $L_{m}$, measured 
in the axes of the pivotal joints, are respectively: $L_{m W l}=27.52 \mathrm{~m}, L_{m W 2}=15.23 \mathrm{~m}$, $L_{m W 3}=18.09 \mathrm{~m}, L_{m W 4}=28.92 \mathrm{~m}$ (Fig. 1). In order to adjust the level of the footbridge deck, the initial tension of the Macalloy rods introduced: $N_{W I}=228.43$ $\mathrm{kN}, N_{W 2}=219.12 \mathrm{kN}, N_{W 3}=208.44 \mathrm{kN}, N_{W 4}=358.40 \mathrm{kN}$.
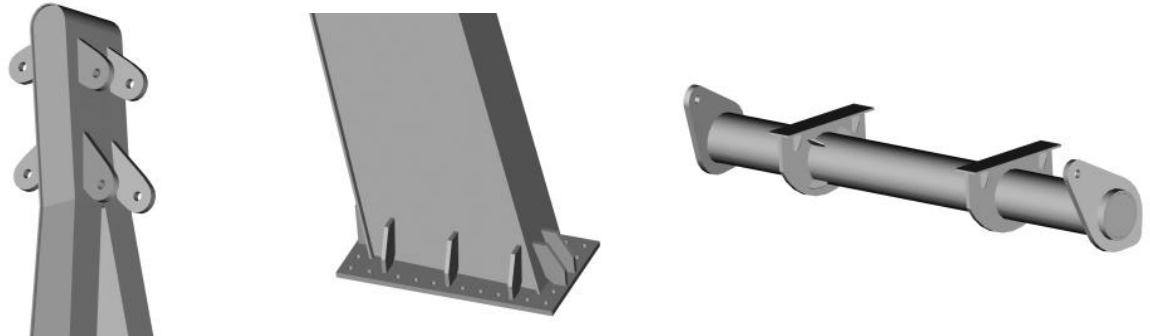

Fig. 4. Selected structural details: pylon head, pylon foot, transverse beam of suspension system

The steel grate of the deck consists of two main girders made of IPE360 rolled sections transversally connected by means of IPE220 rolled beams in a truss system with joints at a spacing of $150 \mathrm{~cm}$.

The footbridge deck is supported on both ends and on intermediate supports by means of elastomeric bearings forming constraints consistent with the diagram shown in Fig. 5.

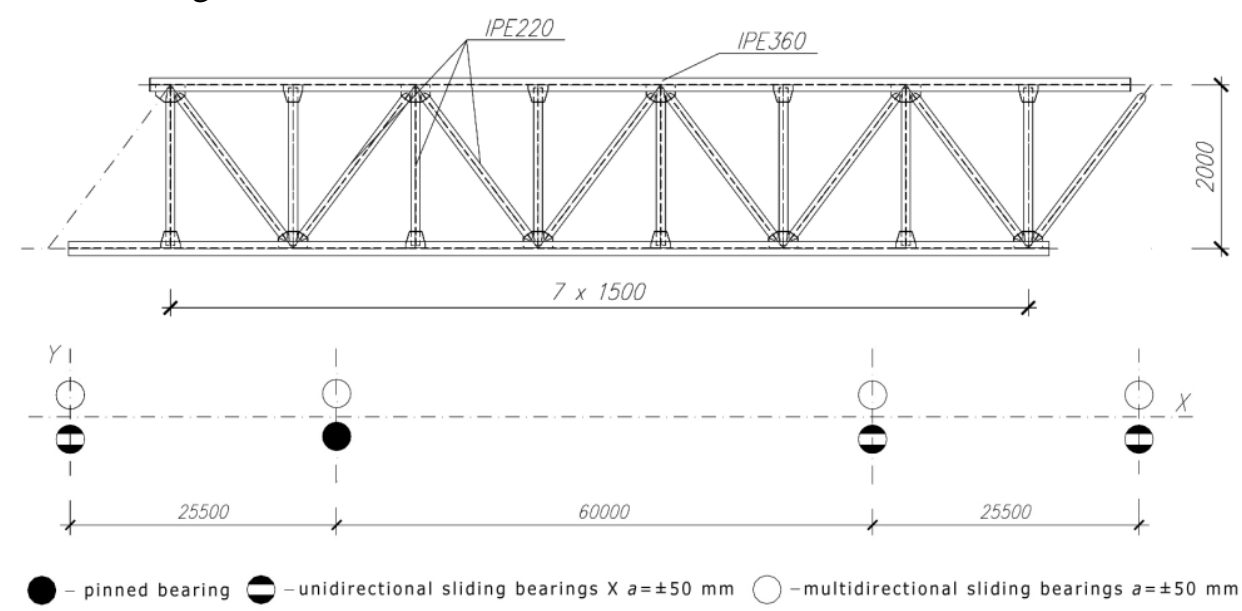

Fig. 5. Structural diagram of the steel grate and arrangement of the support bearings

One pinned bearing, three unidirectional sliding bearings and four multidirectional sliding bearings were used. The bearing capacities of all multidirectional sliding bearings, in three orthogonal directions, are respectively: $F_{x}=$ $F_{y}=0 \mathrm{kN}$ and $F_{z}=500 \mathrm{kN}$. The bearing capacities of unidirectional sliding bearings applied on both abutments are: $F_{x}=0 \mathrm{kN}, F_{y}=50 \mathrm{kN}$ and $F_{z}=500 \mathrm{kN}$.A 
fixed bearing with a bearing capacities on the left-bank pier $F_{x}=F_{y}=300 \mathrm{kN}$ and $F_{z}=4500 \mathrm{kN}$ and on the right-bank pier a unidirectional sliding bearings with a bearing capacities $F_{x}=0 \mathrm{kN}, F_{y}=300 \mathrm{kN}$ and $F_{z}=3000 \mathrm{kN}$ were used.

The footbridge piers were designed in the form of reinforced concrete walls $5.50 \times 3.70 \times 1.00 \mathrm{~m}$ (width $\mathrm{x}$ height $\mathrm{x}$ thickness) with the head widened to $120 \mathrm{~cm}$. On the head of the piers the short reinforced concrete cantilevers $120 \times 82 \times 66 \mathrm{~cm}$ (width $\mathrm{x}$ height $\mathrm{x}$ thickness) forming the supports of the pylons were designed.

The footbridge abutments (Fig. 6) were designed as massive reinforced concrete blocks forming a counterweight to the forces in the pylons back-stay cables anchored in the abutments.
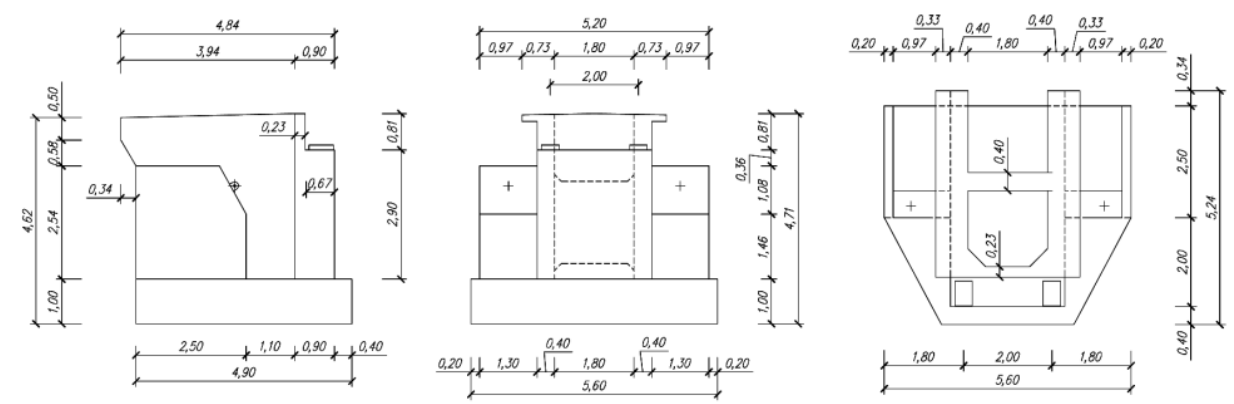

Fig. 6. Footbridge abutments

\section{DYNAMIC ANALYSES OF THE FOOTBRIDGE}

The footbridge is an important traffic route connecting housing estates of single family homes with the centre of Pcim and offices, educational, service and commercial institutions located there.

During free pedestrian traffic (slow and normal walking at frequencies $1.60 \mathrm{~Hz}$ and $1.95 \mathrm{~Hz}$ ), footbridge deck vibrations are easily induced. In cases of dynamic action of single pedestrian and small groups of pedestrians (groups of 2-3 people) the induced vibrations do not disturb the comfort of use of the footbridge. The amplitudes of the vibration acceleration do not exceed the comfort threshold defined for the walking persons. Larger groups of pedestrians induce the vibrations causing discomfort in using the footbridge (induced vibrations slightly disturb walking).

Simultaneously, the vibrations of the back-stay cables of the pylons with the vibrations of the footbridge deck (cables W1, Fig. 1), characterized by large amplitudes of displacement, are excited. The vibrations of back-stay cables are a consequence of the vertical vibrations of the main span of the footbridge and the displacement of the top of the pylons leading to cyclic changes in the value of the tension forces in back-stay cables and parametric vibrations of the cables. 
Field tests and numerical dynamic analysis of the footbridge indicated a significant dependence of the fundamental vibration frequency of the footbridge on the dynamic susceptibility of the pylons' back-stay cables.

\subsection{Computational model}

The mode shapes and natural vibration frequencies of the footbridge were determined during field tests and by numerical calculations using a spatial computational model (Fig. 7).

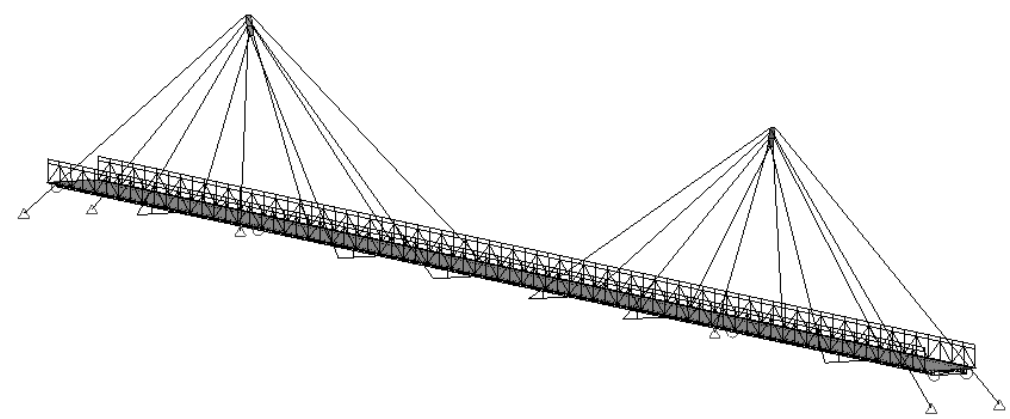

Fig. 7. Spatial computational model of the footbridge

The footbridge deck was modeled as a steel grate (with rigid connection between elements) cooperating with a reinforced concrete slab. The grate was modeled using beam elements. The footbridge slab was modeled using plate elements with variable thicknesses of $17 \mathrm{~cm}$ in the central area of the slab (3.0 m wide) and $20 \mathrm{~cm}$ in the edge zones. The computational model takes into account the exact position of the footbridge deck components (girders and slab) relative to each other which was ensured by introducing rigid spacer beam elements connecting the centre of gravity of the steel girders and concrete slab.

In order to properly model the vibrating mass of the system, a substitutive volumetric weight of the footbridge reinforced concrete slab was determined taking into account the presence of the epoxy pavement in the central part of the deck and polymer concrete parapet panels in the edge zones of the slab. The substitutive volumetric weight of the concrete slab was determined for the central part of the slab as $\gamma_{m l}=25.6 \mathrm{kN} / \mathrm{m}^{3}$ and for edge zones as $\gamma_{m 2}=30.0 \mathrm{kN} / \mathrm{m}^{3}$. A steel balustrade with geometry consistent with the executive design of the footbridge was modeledin the edge zones of the slab.

The footbridge pylons were modeled using beam elements with variable cross section geometry consistent with the executive design of the footbridge (Fig. 3). Full fixing of the pylons in the foundations was assumed.

The deck suspension points were modeled using beam elements, taking into account the exact distances between the centres of gravity of the longitudinal girders IPE360 and transverse beams of the $\varnothing 406.4 / 28$ suspension system. The 
connections of the IPE360 longitudinal girders with $\varnothing 406.4 / 28$ transverse beamswere modeled using rigid spacer beam elements.

The stay cables were modeled as beam elements pivotally connected with pylons and transverse suspension beams. The model does not include the pretension of the stay cables.

The following modulus of elasticity were used in the calculations: steel 18G2 $E_{s}=210 \mathrm{GPa}$ [2], concrete $\mathrm{C} 30 / 37 E_{c m}=32,6 \mathrm{GPa}$ [3], Macalloy rods $E_{v}=205 \mathrm{GPa}[4]$.

\subsection{Dynamic characteristic of the footbridge}

The dynamic characteristics of the footbridge were determined during field tests and by numerical analyses. The numerical analyses included several variants of the computational model with modified parameters of freedom of displacement of the stay cables' anchor points and freedom of displacement of the deck supporting elastomeric bearings. In particular, computational models of the coefficients of elasticity of the supporting points were modified. It should be noted that modifications of the parameters of the computational model influenced only the changes in the vibration frequency of the structure and did not change the mode shapes of the structure.

The mode shapes and the natural vibration frequencies of the footbridge are respectively presented in Fig. 8 and in Tab. 1. The natural vibration frequencies presented in Tab. 1 were identified during field tests and were the benchmark for evaluating the results of numerical modal analyses of the footbridge.

a)

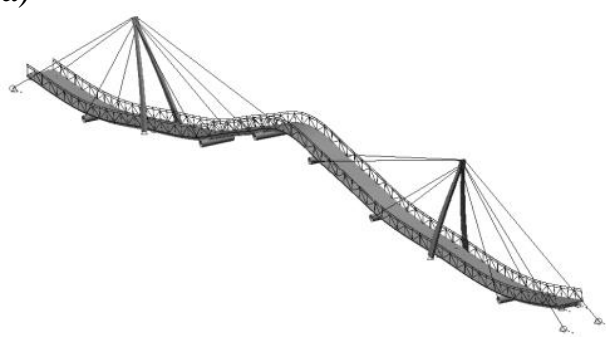

c)

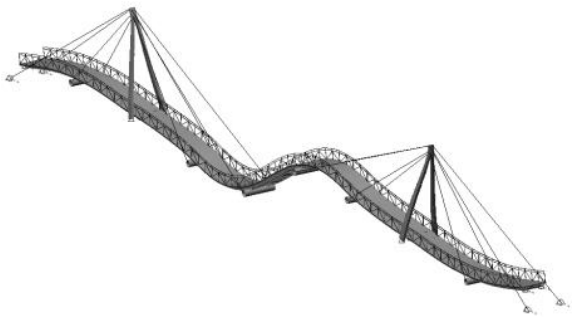

b)

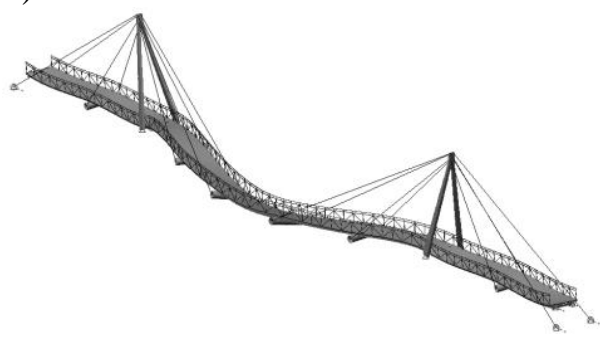

d)

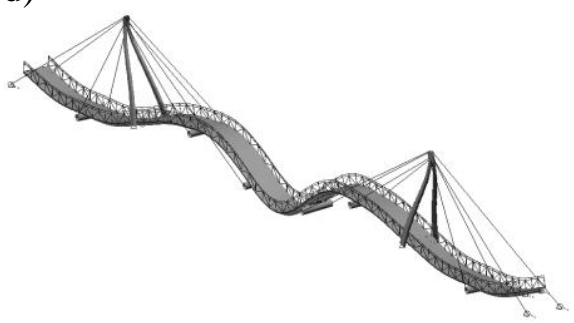


e)

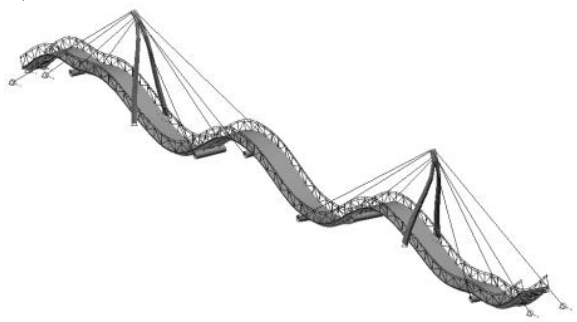

f)

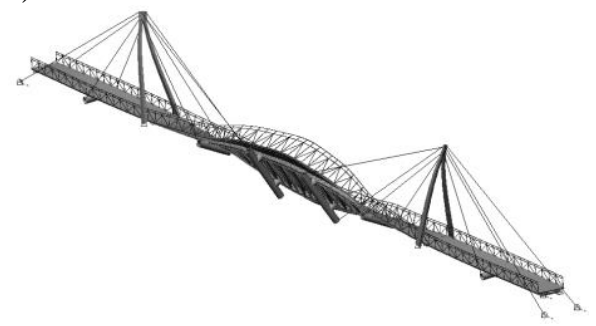

Fig. 8. Mode shape of the footbridge a) vertical vibration, b) horizontal vibration, c) vertical vibration, d) vertical vibration, e) vertical vibration $\mathrm{f}$ ) torsional vibration

Table 1. Mode shapes and natural vibration frequencies of the footbridge identified during field tests

\begin{tabular}{|c|c|l|}
\hline Number of mode shape & Frequency[Hz] & \multicolumn{1}{|c|}{ Mode shape } \\
\hline 1 & 1.61 & Vertical vibration \\
\hline 2 & 2.32 & Horizontal vibration \\
\hline 3 & 2.54 & Vertical vibration \\
\hline 4 & 3.61 & Vertical vibration \\
\hline 5 & 4.54 & Vertical vibration \\
\hline 6 & 4.88 & Torsional vibration \\
\hline
\end{tabular}

In the first variant of the computational model (computational model no. 1) the footbridge support conditions assuming an idealized freedom of displacement of the structure in accordance with the support bearings scheme (Fig. 5) were modeled. The support conditions providing full freedom of rotation on all bearings, full freedom of longitudinal displacements on unidirectional bearings, full freedom of longitudinal and transverse displacement on multidirectional bearings and non-sliding pivot joint (pinned support) of the pylons back-stay cables in the abutments were assumed. In computational model no. 1 the elasticity of the bearings, resulting from the use of the elastomer in their construction, was omitted.

The natural vibration frequencies of the footbridge obtained for the computational model no. 1 are presented in Tab. 2.

Table 2. Mode shapes and natural vibration frequencies of the footbridge obtained for the computational model no. 1

\begin{tabular}{|c|c|l|}
\hline Number of mode shape & Frequency[Hz] & \multicolumn{1}{c|}{ Mode shape } \\
\hline 1 & 1.80 & Vertical vibration \\
\hline 2 & 2.15 & Horizontal vibration \\
\hline 3 & 2.54 & Vertical vibration \\
\hline 4 & 3.62 & Vertical vibration \\
\hline 5 & 4.30 & Vertical vibration \\
\hline 6 & 4.47 & Torsional vibration \\
\hline
\end{tabular}


It can be noted that in comparison with the natural vibration frequencies identified during field tests (Tab. 1) the vibration frequency of the first mode shape obtained during numerical analysis has a higher value and the vibration frequency of the second mode shape has a lower value. Obtained results, assuming correct modeling of the stiffness and mass of the structural system, may indicate an inaccurate representation of the freedom of displacement of the support points in computational model no. 1 . In the case of the first mode shape, modeling inaccuracies are related to the excessive limitation of the freedom of displacement of the structure in the longitudinal direction (parallel to the longitudinal axis of the footbridge) leading to an increase in the frequency of the first mode shape. In the case of the second mode shape, modeling inaccuracies are related to the increased freedom of displacement, which leads to a decrease in the vibration frequency of the second mode shape. Further analyses have shown that the changes in the freedom of displacement of the structure in the longitudinal direction parallel to the longitudinal axis of the footbridge ( $X$ axis) affect both the frequency of the first (vertical) and the second (transverse) mode shape of the footbridge.

Essential information to explain the situation and modifying the parameters of the computational model were provided by field tests. Large amplitudes of displacement of back-stay cables were observed during the dynamic field tests of the footbridge, in the vertical direction perpendicular to the axis of the cables. The vibrations occurred during excitation of the first mode shape of the footbridge with a frequency of $f_{l}=1.61 \mathrm{~Hz}$. The measurements of the vibration frequency of the back-stay cables showed that the natural frequency of the back-stay cables is $f_{W l} \approx 1.91 \mathrm{~Hz}$. The difference between the vibration frequency of the footbridge deck $f_{l}=1.61 \mathrm{~Hz}$ and the vibration frequency of the pylons back-stay cables $f_{W l} \approx 1.91$ Hzindicates that the vibrations of the pylons back-stay cables are not resonant vibrations of thepylons back-stay cables.

It was considered that the vibrations of the pylons back-stay cables are induced by the displacement of the top of the pylons occurring during the vibrations of the footbridge deck corresponding to the first mode shape leading to a changes in the tensile force of the back-stay cables and consequently to excitation of the vibrations of the back-stay cables - parametric vibrations of the cables [5].

Moreover, it was also recognized that due to the occurrence of large amplitude of vibrations of the pylons back-stay cables, the parameters of the structural system change leading to the change of the first natural vibration frequency of the footbridge. The observed effect required consideration in the computational model. It was assumed that the vibration of the pylons' back-stay cables increasing the freedom of displacement of the top of the pylons. Increased freedom of displacement of the top of pylons was included in the computational model by modifying the method of anchoring of the back-stay cables to the 
abutments. The anchorages were modeled as pinned spring supports providing the possibility of elastic displacement in the direction of the $X$ axis parallel to the longitudinal axis of the footbridge (computational model no. 2). Parameters of the remaining supports (elastomeric bearings) in computational model no. 2 were left unchanged (were adopted as in computational model no. 1 assuming idealized freedom of displacement and rotation of the support bearings).

Compatibility of the first vibration frequency of computational model no. 2 with the first natural vibration frequency obtained during the filed tests was obtained assuming the longitudinal spring stiffness (parallel to the longitudinal axis of the footbridge) $k_{x, W l}=23,0 \mathrm{MN} / \mathrm{m}$. The vibration frequencies of the remaining mode shapes of the footbridge for computational model no. 2 are presented in Tab. 3 . In the case of the vertical vibrations (mode shapes no. 3, 4, 5) the vibration frequencies have decreased. For transverse vibration (mode shape no. 2) the vibration frequency has remained unchanged.

Table 3. Mode shapes and natural vibration frequencies of the footbridge obtained for computational model no. 2

\begin{tabular}{|c|c|l|}
\hline Number of mode shape & Frequency[Hz] & \multicolumn{1}{|c|}{ Mode shape } \\
\hline 1 & 1.61 & Vertical vibration \\
\hline 2 & 2.15 & Horizontal vibration \\
\hline 3 & 2.33 & Vertical vibration \\
\hline 4 & 3.52 & Vertical vibration \\
\hline 5 & 4.25 & Vertical vibration \\
\hline 6 & 4.45 & Torsional vibration \\
\hline
\end{tabular}

During the numerical analyses it was noted that the frequency of the first mode shape of the footbridge strongly depends solely on the value of the longitudinal spring stiffness of the pinned spring supports used to anchor the pylons' back-stay cables in the abutments. Simultaneously, this frequency was insensitive to changes in the freedom of displacement of the remaining supporting bearings. For example, full fixing of longitudinal and lateral displacements of all support bearings, while maintaining the elastic anchorage of the back-stay cables in the abutment, slightly increase the vibration frequency of the first mode shape to $f_{l}=1.65 \mathrm{~Hz}$. Simultaneously, it was noted that in the case of fully fixed longitudinal and lateral displacements of the support bearings, the frequency of the second mode shape of the footbridge increased to $2.65 \mathrm{~Hz}$. This proves the high sensitivity of the vibration frequency of the second mode shape of the footbridge to the changes in freedom of displacement of the support bearings. During further analyses, it was found that the increasing of the frequency of the second mode shape of the footbridge (transverse vibration) depends mainly on the fixing of the freedom of displacement of the support bearings in the longitudinal direction parallel to the axis of the footbridge. Moreover, results of analyses of computational models no. 1 and 2 indicated that the frequency of the second mode 
shape (transverse vibration) is not sensitive to changes of the longitudinal spring stiffness of the pinned spring supports anchoring the back-stay cables in the abutments.

In order to investigate the possibility of adjusting the vibration frequency of the second mode shape to the value obtained during the field tests, an attempt was made to modify the spring stiffness of the elastomeric bearings. The analyses were performed using computational model no. 3 constructed by introducing a complete fixing of the longitudinal displacement (parallel to the longitudinal axis of the footbridge) of all unidirectional bearings (see Fig. 4) and limiting the longitudinal displacements on all multidirectional bearings by introducing spring supports with spring stiffness $k_{x, e l}=60.0 \mathrm{MN} / \mathrm{m}\left(k_{x, e l} \mathrm{value}\right.$ was determined by successive approximations, looking for a spring stiffness which would guarantee the corresponding value of the vibration frequencies of the structure). In computational model no. 3 the value of the longitudinal spring stiffness of the spring supports anchoring the pylons back-stay cables in the abutments was assumed as in computational model no. $2\left(k_{x, w l}=23,0 \mathrm{MN} / \mathrm{m}\right)$. The natural vibration frequencies of the footbridge obtained for the computational model no. 3 are presented in Tab. 4 .

Table 4. Mode shapes and natural vibration frequencies of the footbridge obtained for the computational model no. 3

\begin{tabular}{|c|c|l|}
\hline Number of mode shape & Frequency $[\mathrm{Hz}]$ & \multicolumn{1}{|c|}{ Mode shape } \\
\hline 1 & 1.63 & Vertical vibration \\
\hline 2 & 2.32 & Horizontal vibration \\
\hline 3 & 2.38 & Vertical vibration \\
\hline 4 & 3.67 & Vertical vibration \\
\hline 5 & 4.36 & Vertical vibration \\
\hline 6 & 4.46 & Torsional vibration \\
\hline
\end{tabular}

In computational model no. 3 the frequency of the first mode shape of the footbridge was slightly increased. Readjustment of the frequency of the first mode shape to the value of $f_{l}=1.61 \mathrm{~Hz}$ was achieved by decreasing of the longitudinal spring stiffness of the back-stay cables' spring supports to the value of $k_{x}$, ${ }_{w l}=20.0 \mathrm{MN} / \mathrm{m}$. The new computational model was marked as computational model no. 4. The introduced change in longitudinal spring stiffness did not affect the value of the frequency of the second mode shape of the footbridge (Tab. 5).

Table 5. Mode shapes and natural vibration frequencies of the footbridge obtained for computational model no. 4

\begin{tabular}{|c|c|l|}
\hline Number of mode shape & Frequency[Hz] & \multicolumn{1}{|c|}{ Mode shape } \\
\hline 1 & 1.61 & Vertical vibration \\
\hline 2 & 2.32 & Horizontal vibration \\
\hline 3 & 2.35 & Vertical vibration \\
\hline
\end{tabular}




\begin{tabular}{|l|l|l|}
\hline 4 & 3.66 & Vertical vibration \\
\hline 5 & 4.35 & Vertical vibration \\
\hline 6 & 4.45 & Torsional vibration \\
\hline
\end{tabular}

Computational model no. 4 was acknowledge to be the final variant of the computational model, which will allow to predict the dynamic response of the structure in further analyses of forced vibration.

\section{SUMMARY AND CONCLUSIONS}

The paper presents the results of dynamic field tests and numerical analyses of cable stayed pedestrian bridge characterized by increased dynamic susceptibility of elements of the suspension system and the occurrence of large amplitude parametric vibrations of the pylons' back-stay cables.

The analyses have enabled to identify the parameters of the computational model which significantly influenced the change of the vibration frequencies of the footbridge, which have proved to be the freedom of displacement of anchor points of the pylons back-stay cables in the abutments and the freedom of displacement of the support elastomeric bearings in the longitudinal direction parallel to the longitudinal axis of the footbridge.

Based on the results of the field tests, it was assumed that the parametric vibrations of the pylons back-stay cables caused by the vertical vibrations of the footbridge deck and the displacement of the top of pylons results in a change of pylon stabilization conditions by the back-stay cables which consequently leads to change the value of the vibration frequency of the first mode shape of the footbridge.

The correct determination of the frequency of the first mode shape of the footbridge, consistent with the frequency identified during the field tests, has required the use of the spring supports anchoring the pylon back-stay cables with abutments in the computational model. The anchoring of the pylon back-stay cables to the abutments by means of spring supports (elastic supports) has increased the freedom of displacement of the top of pylons and reduced the fundamental vibration frequency of computational model no. 1 to the value identified during the field tests.

In order to adjust the frequency of the second mode shape of the footbridges to the field tests results, it was necessary to fully constrain the longitudinal displacements of all unidirectional sliding bearings and to limit the freedom of the longitudinal displacement of the multidirectional bearings by using the elastic supports with a suitable value of the coefficient of elasticity (suitable spring stiffness).

It should be noted that the exact value of the vibration frequencies of the mode shapes no. 3 and 4 were determined by using the computational model no. 1 with 
the unmovable, inflexible (non elastic) pinned supports connecting the pylon back-stay cables with the abutments and idealized freedom of displacement of elastomeric bearings. It can be considered that the computational model no. 1 accurately reflects the parameters of the construction system occurring in the situation of the absence of vibration of the pylons back-stay cables and allowing to accurately determine the frequency of higher mode shapes of the footbridge (mode shapes no. 3 and 4). However, it was finally recognized that computational model no. 4 allows for accurate determination of the vibration frequencies of a larger number of mode shapes, and therefore as a more accurate computational model, it will be used in further dynamic analysis of the footbridge. Nevertheless, it should be also noted that dynamic analyses of the structures characterized by occurrence of the parametric vibration of the structural elements are often multistage analyses using different variants of the computational model to estimate the dynamic response of the structure for different vibration frequencies. In these cases, the computational models are prepared assuming their proper functionality within a strictly defined range of the structural system vibration frequency. This approach allows for the use the computational model no. 1 in further dynamic analyses to assess dynamic susceptibility and to estimate the dynamic response of the structure to dynamic impacts of the users (running or jumping) at a frequency corresponding to the mode shape no. 3 .

The presented results of field tests and numerical analyses of cable-stayed pedestrian bridge indicate the need of accurate identification of the dynamic susceptibility of the elements of the suspension system responsible for limiting the freedom of displacement of the pylons - the pylons back-stay cables.

In order to correctly identify the basic dynamic characteristics of the cable-stayed structures, it may be important to evaluate the possibility of occurrence of parametric vibrations of the pylons back-stay cables and to determine the influence of these vibrations on changes in the parameters of the structural system. The issue of the dynamic susceptibility of the pylons back-stay cables is particularly important in the case of the structures with a small number of the pylons back-stay cables. The vibrations of the pylons back-stay cables characterized by high-amplitude transverse displacement can lead to greater freedom of displacement of the structural system (freedom of displacement of the pylons and the deck) and to the lower vibration frequency of the structure and consequently to greater dynamic susceptibility of the structure to environmental and operational dynamic loads. Structural solutions containing larger number of the pylons back-stay cables, properly anchored in massive and non-susceptible anchor blocks and supporting each other in carrying loads and stabilizing pylons should be considered as morefavourable. 


\section{ANALIZY PARAMETRYCZNE CHARAKTERYSTYK DYNAMICZNYCH PODWIESZONEJ KŁADKI DLA PIESZYCH}

\section{Streszczenie}

W referacie przedstawiono charakterystykę układu konstrukcyjnego oraz wyniki dynamicznych badań terenowych i analiz numerycznych trójprzęsłowej, dwupylonowej, podwieszonej kładki dla pieszych $\mathrm{z}$ pomostem zespolonym stalowo-betonowym o rozpiętościach przęseł $25,5+60,0+25,5 \mathrm{~m}$. Kładka odznacza się zwiększoną podatnością dynamiczną elementów układu podwieszenia obserwowaną podczas codziennej eksploatacji konstrukcji. Wykonane analizy wykazały, iż występujące drgania want odciągowych o dużych amplitudach wpływają na zmianę parametrów układu konstrukcyjnego i w konsekwencji zmianę wartości częstotliwości drgań własnych konstrukcji. W pracy przedstawiono wyniki analiz i badań terenowych obrazujące zależność charakterystyk dynamicznych kładki od podatności dynamicznej want odciągowych i swobody przemieszczeń pylonów. Scharakteryzowano metodykę doboru parametrów modelu obliczeniowego pozwalającą na poprawne wyznaczenie częstotliwości drgań własnych konstrukcji.

Słowa kluczowe: drgania, kładki dla pieszych, analizy parametryczne, charakterystyki dynamiczne

Editor received the manuscript: 08.09.2017 